\title{
画像所見以外で脊椎カリエスと化膿性脊椎炎とを 鑑別する際に有用な因子は何か
}

\author{
井上 三四郎* 吉 田 裕 俊* 幸 博 和*
}

\begin{abstract}
【目的】画像所見以外での春椎カリエスと化膿性脊椎炎とを鑑別する因子を同定すること.【対象と方 法】春椎カリエス 25 例と化膿性脊椎炎 35 例を対象とした. 検討項目は, 年齢・性別・糖尿病, 治療中 の悪性腫瘍, 透析など易感染性を示唆する既往歴（以下既往歴）・脊椎以外の他臟器における活動性結 核の合併 (以下他臟器結核) ・病変部位・入院時白血球数・入院時 $\mathrm{CRP}$ の 7 項目である. 統計ソフトは Statcel 3 と EZR を使用し $\mathrm{P}<0.05$ を有意差ありとした.【結果】単変量解析で, 性別, 既往歴, 他臓器 結核, 病変部位, 入院時白血球数に有意差あり。多変量解析で, 他藏器結核と既往歴に有意差あり。【考 察】化膿性春椎炎と春椎カリエスとを鑑別するポイントは, 他臟器結核と既往歴であった. 他臟器結核, 特に肺結核の精査は, 集団感染予防という点からも重要である.
\end{abstract}

Key words : pyogenic spondylitis（化膿性春椎炎）, tuberculous spondylitis（結核性脊椎炎）, diangosis (診断)

はじめに

整形外科を受診する腰痛患者は多く, 春椎を専門と しない整形外科医もその診療にあたる機会は多い。そ の中には, 必然的に脊椎カリエスや化膿性脊椎炎が含 まれている.

両者では治療方針が異なるためにその鑑別が重要で ある. 更に脊椎カリエスであれば結核病棟を有する病 院への転送を迫られることも多く, 主治医の肩にかか る責任は重い，生検が最も鑑別に有用な検查であるこ とに異論はない.しかし，この検查は侵襲的であり， 脊椎非専門医には荷が重い。脊椎カリエスと化膿性脊 椎炎との鑑別に, 画像診断特に MRI が有用との報告 は多( ${ }^{61010}$ 。一方で，画像のみでは鑑別困難な症例が 存在することも事実である.

本稿の目的は, 一般整形外科医が両者の診断に迷う 患者を目にした際に，画像所見以外でその鑑別に有用 な因子を同定することである.

\section{対象と方法}

脊椎カリエスの対象は 2009 年から 2014 年までに当 院で治療を行った 25 例である. 全ての患者はカルテ を基に調查された. 診断は, 細菌学的検査・病理学的
検査・抗結核薬投与に対する反応などの臨床経過から 総合的に判断した. なおこの群については既に報告し ている4).

化膿性脊椎炎の対象は, 2013 年 4 月から 2016 年 10 月までに当院で入院加療を行った 35 例である. 全て の患者はカルテを基に調查された. 診断は, 細菌学的 検査・病理学的検查・抗菌薬投与に対する反応などの 臨床経過から総合的に判断した. なおこの群について も既に報告している5 .

検討項目は, 年齢 - 性別 - 糖尿病, 肝炎 - 肝硬変, 治療中の悪性腫瘍，ステロイド内服中の膠原病，透析 などの易感染性を示唆する既往歴（以下既往歷）・病 変部位 (主病変の部位にて記載) ・脊椎以外の他臟器 における活動性結核の合併 (以下他藏器結核), 入院 時白血球数 (以下白血球数) - 入院時 $\mathrm{CRP}$ の 6 項目 である. 年齢は 75 歳以下か否か, 白血球数は 1 万 $\mu \mathrm{l}$ 以下か否か, 入院時 $\mathrm{CRP}$ が $5.0 \mathrm{mg} / \mathrm{dl}$ 以下か否かで も, 検討した.

単変量解析の統計ソフトには Statcel 3 を使用し ${ }^{12}$, スチューデントの $\mathrm{t}$ 検定, $\chi^{2}$ 検定，フィッシャーの 直接確率計算法を行った. $\mathrm{P}<0.05$ を有意差ありとし た. 多変量解析の統計ソフトには EZR を使用し ${ }^{7)}$ 、 ロ ジステック回帰分析を行った。単変量解析で有意差が

\footnotetext{
* 福岡東医療センター整形外科
} 
あった項目の他, $\mathrm{P}<0.15$ を示す項目も説明変数とし て選択し, $\mathrm{p}$ 值を用いたステップワイズの変数選択 （減少法）を行った. $\mathrm{P}<0.05$ を有意差ありとした.

結果

両群の調査項目と単変量解析の結果を表 1 に示す. 単変量解析では, 性別, 免疫不全, 既往歴, 他臓器結 核, 病変部位, 白血球数で有意差があった. 多変量解 析の結果は表 2 に示す．他臟器結核と既往歷で有意差 があつた。この 2 つの因子を用いて, 表 3 に示すよう に患者を 4 パターンに分類し, 脊椎カリエスの可能性 を推測する早見表を作成した，例えば，他臟器結核と 既往歴の両方を有する患者では，春椎カリエスの可能
性は $88.9 \%$ となる.

考察

本研究では, 単変量解析では, 性別, 免疫不全, 既 往歴, 他臟器結核, 病変部位, 白血球数に有意差が あった. 多変量解析では, 他藏器結核と既往歴に有意 差があった.

これらは，過去の報告とも概ね合致する．Yoon ら は ${ }^{13)}$ ，脊椎カリエスを示唆する項目として，女性，非 腰椎病変, 7 日以上の診断遅延, $9600 / \mathrm{mm}^{3}$ 以下の白 血球低值, $3.0 \mathrm{mg} / \mathrm{dL}$ 以上の血清アルブミンと 1.39 $\mathrm{ng} / \mathrm{dL}$ 以下のプロカルシトニン值の組み合わせ，非 春椎病変と $7.25 \mathrm{mg} / \mathrm{L}$ 以下の $\mathrm{CRP}$ 值の組み合わせを

表 1 単変量解析

\begin{tabular}{|c|c|c|c|}
\hline 項目 & 脊椎カリエス & 化膿性脊椎炎 & 有意差 \\
\hline 年齢（歳） & $75.5 \pm 13.4$ & $70.5 \pm 10.6 \quad(49 \sim 90)$ & 0.114348 \\
\hline $\begin{array}{c}\text { 年齢 }(人) \\
\leqq 75 \text { 歳, } 75 \text { 歳 }<\end{array}$ & $\leqq 75 \quad 11 / 75<14$ & $\leqq 75 \quad 23 / 75<12$ & 0.079376 \\
\hline 性別（人） & 男 8/女 17 & 男 $23 /$ 女 12 & 0.009983 \\
\hline $\begin{array}{c}\text { 免疫不全を示唆する } \\
\text { 既往歴（人） }\end{array}$ & あり 8/ なし 17 & あり $22 /$ なし 13 & 0.018435 \\
\hline 他臓器結核の合併（人） & あり $16 /$ なし 9 & あり $1 /$ なし 34 & 0.00000022 \\
\hline 病変部位（人） & 非腰椎 $17 /$ 腰椎 8 & 非腰椎 12 / 腰椎 23 & 0.009983 \\
\hline WBC $(/ \mu \mathrm{l})$ & $6000 \pm 1866$ & $7728 \pm 2416$ & 0.004055 \\
\hline $\begin{array}{c}\text { WBC (人) } \\
\leqq 1 \text { 万 } / \mu \mathrm{l}, 1 \text { 万 } / \mu \mathrm{l}<\end{array}$ & $\leqq 1$ 万 $24 / 1$ 万 $<1$ & $\leqq 1$ 万 $28 / 1$ 万 $<7$ & 0.074903 \\
\hline CRP (mg/dl) & $2.84 \pm 4.02$ & $5.26 \pm 0.19 \quad(0.08 \sim 16.93)$ & 0.170281 \\
\hline $\begin{aligned} \text { CRP } & \text { (人) } \\
\leqq 5.0 \mathrm{mg} / \mathrm{dl}, & 5.0 \mathrm{mg} / \mathrm{dl}<\end{aligned}$ & $\leqq 5.0 \quad 16 / 5.0<9$ & $\leqq 5.0 \quad 19 / 5.0<16$ & 0.451771 \\
\hline
\end{tabular}

表 2 多変量解析

\begin{tabular}{l|c|c|c|c}
\hline \hline \multicolumn{1}{c|}{ 説明変数 } & オッズ比 & $\begin{array}{c}95 \% \text { 信頼 } \\
\text { 区域下限 }\end{array}$ & $\begin{array}{c}95 \% \text { 信頼 } \\
\text { 区域上限 }\end{array}$ & $\mathrm{P}$ 值 \\
\hline (intercept) & 0.562 & 0.2280 & 1.380 & 0.209000 \\
\hline 他臟器結核の合併 & 90.100 & 8.4000 & 968.000 & 0.000202 \\
\hline $\begin{array}{l}\text { 免疫不全を示唆する } \\
\text { 既往歴 }\end{array}$ & 0.152 & 0.0285 & 0.808 & 0.027100 \\
\hline
\end{tabular}


表 3 早見表

\begin{tabular}{c|c|c|c|c}
\hline \hline $\begin{array}{c}\text { 他臟器結核 } \\
\text { の合併 }\end{array}$ & $\begin{array}{c}\text { 免疫不全を示唆 } \\
\text { する既往歴 }\end{array}$ & 症例数 (人) & $\begin{array}{c}\text { 脊椎カリエス } \\
\text { の症例数(人) }\end{array}$ & $\begin{array}{c}\text { 脊椎カリエス } \\
\text { の可能性 }(\%)\end{array}$ \\
\hline あり & なし & 8 & 8 & 100 \\
\hline あり & あり & 9 & 8 & 88.8 \\
\hline なし & なし & 20 & 7 & 35.0 \\
\hline なし & あり & 23 & 2 & 8.69 \\
\hline
\end{tabular}

挙げている. Kim らは ${ }^{8)}$, 春椎手術の既往, 先行する 菌血症, 白血球数高值, 好中球高値, $\mathrm{CRP}$ 高値, 血 沈高值, 血性アルカリフォスファターゼは化膿性脊椎 炎を示唆し, 併存する他臟器の活動性結核と胸椎病変 は脊椎カリエスを示唆すると述べている.

脊椎カリエスと化膿性脊椎炎との鑑別に，画像診断 特に MRI は確かに有用である(1)10). しかし,ペースメー カーや閉所恐怖症のため MRI が撮影不能な症例や透 析患者で造影が禁忌となる症例も存在し，MRIがそ もそも設置されていない医療機関もある，更に，麻生 と上谷が述べるように2)，実際には，画像のみでは両 者の鑑別は容易ではないことが多いのも事実である. Ahn ら ${ }^{1)}$ は, 化膿性脊椎炎から脊椎カリエスへと診断 変更した 4 例と逆に春椎カリエスから化膿性春椎炎へ と診断を変更した 3 例を報告している. 彼らの報告は, 実臨床における鑑別の困難さを示唆している.

それでは，生検や MRI 以外で，両者を鑑別する際 に最も重要な因子は何であろうか。私は, 他臓器結核, 特にその大多数を占める肺結核の有無と考える。 そし て，それは単に統計学上の数字のみが理由ではない. それ以外の社会的な理由から，肺結核の合併を検索す ることは非常に重要である，なぜなら，活動性の肺結 核を持つ脊椎カリエス患者を一般病棟に入院させれ ば，医師や看護師そして他の患者への集団感染の引き 金となるからである9.

では，一般整形外科医にとって，両者の鑑別の際に 有用な検查は何であろうか。私が推奨したいのは，喀 痰検查と胸部 CT である。喀痰検查は結核菌の存在を 細菌学的に証明するためである．CT を薦める理由は 2 つある. 一つ目の理由は, 空間分析能に優れ病変の 検出力が高く, ある一定規模以上の病院には設置され ているからである。整形外科医は胸部 X 線読影が苦 手であるが11)，単純 X 線と違い通常は放射線医が読
影した報告書がつくのも魅力である．もうひとつの理 由は，転移性腫瘍が否定できる点である，感染性脊椎 炎の鑑別のひとつに転移性腫瘍が挙がるが，胸部 CT を撮影すればその一助となる，つまり，化膿性脊椎炎 や脊椎カリエスを疑う患者が来た場合には，ルーチン で胸部 CT を撮影することを推奨する.

本研究の限界として，以下の三点が挙げられる。一 点目は, クオンティフェロンや $\mathrm{T}$ spot を検討してい ないことである.このシリーズでは計測されていない 症例も多く，検討から除外した。これらは鑑別に有用 である可能性がある。二点目は，この結果が他施設に あてはまるかどうかが不明な点である．当院の前身は 結核療養所であり, 多くの脊椎カリエスの患者が紹介 される ${ }^{4) 5}$. 肺結核を有し排菌している患者は, 結核病 棟を有する当院へ積極的に紹介されるだろう。一方， 排菌していない患者は，紹介されずに引き続き診断さ れた病院で治療されているかもしれない.つまり, 肺 結核に関してはセレクションバイアスが入っている可 能性がある. さらに, 化膿性脊椎炎患者についても, 結核病棟を有する当院ならではのバイアスが含まれる 可能性がある ${ }^{5}$. 三点目は, 化膿性脊椎炎の診断である. このシリーズでは起炎菌が同定された症例は 35 例中 15 例 $(42.8 \%)$ であった ${ }^{5}$. 全例に血液培養もしくは 椎体生検を行つたが, 血液培養のみを行った症例も 12 例あった")。つまり, 全例に椎体生検を行つている わけではない，椎体から細菌が検出された症例のみを 化膿性脊椎炎の確定例とする立場からすると，診断に 疑問は残るだろう。我々はガイドラインやレビューも 参考にして ${ }^{3 / 14)}$ ，特に血液培養陽性例には椎体生検は 必須とせず，起炎菌も必ずしも検出されないという立 場をとった，化膿性春椎炎の診断は，細菌学的検查・ 病理学的検査・抗菌薬投与に対する反応などの臨床経 過から総合的に行った. 
結語

当院で加療した脊椎カリエス 25 例と化膿性脊椎炎 35 例に対して，画像所見以外でその鑑別に有用な因 子を検討した. 単変量解析で, 性別, 既往歴, 他藏器 結核，病変部位，白血球数に有意差があった．多変量 解析で，他臓器結核と既往歴に有意差があつた。他臓 器結核，特に肺結核の精査は，集団感染予防という点 からも重要であり, 喀痰検査や胸部 CT を積極的に行 うべきである.

\section{参 考 文 献}

1) Ahn, J.S., Lee, J. K.: Diagnosis and treatment of tuberculous spondylitis and pyogenic spondylitis in atypical cases. Asian Spinal J., $1: 75-79,2007$.

2) 麻生鴨哉, 上谷雅孝：感染性脊椎炎。骨軟部疾患の画 像診断（第一版）, pp.206-207. 上谷雅孝（編），東京， 秀潤社, 1999.

3) Berbari, E. F., et al.: 2015 infectious disease society of America (IDSA) clinical practice guideline for the diagnosis and treatment of native vertebral osteomyelitis in adults. Clin. Infect. Dis., 61: e26-e46, 2016.

4）井上三四郎ら：当院での結核性脊椎炎の診断と治療 第 2 報. 整外と災外, $65: 88-90,2016$.
5）井上三四郎，吉田裕俊，幸 博和：結核病棟を有する 結核指定医療機関における化膿性春椎炎. 整外と災外, $67: 279-282,2018$

6) Jung, N. Y., et al.: Discrimination of tuberculous spondylitis from pyogenic spondylitis on MRI. Am. J. Roentgenol., 182 : 1405-1410, 2004.

7) Kanda, Y.: Investigation of the freely available easy -to-use software 'EZR' for medical statistics. Bone Marrow Transplant., 48 : 452-458, 2013.

8) Kim, C. J., et al.: A comparative study of pyogenic and tuberculous spondylodiscitis. Spine, 35: E1096-E1100, 2010.

9）日本結核病学会予防委員会：医療施設内結核感染対策 について. 結核, 85:477-481, 2010.

10) Park, J.H., et al.: Differentiation between tuberculous spondylitis and pyogenic spondylitis on MR Imaging. Korean J. Spine, $8: 283-287,2011$.

11）山崎隆志ら：整形外科医は胸部 $X$ 線像が苦手か？．整 形外科, $55: 1365-1368,2004$.

12）柳井久江：4 steps エクセル統計（第3版）。埼玉，オー エムエス出版, 2011.

13) Yoon, Y.K., et al.: Diffential diagnosis between tuberculous spondylodiscitis and pyogenic spontaneous spondylodiscitis: a multicenter descriptive and comparative study. Spine J, $15: 1764-1771$, 2015.

14) Zimmerli, W.: Vertebral osteomyelitis. N. Eng. J. Med., 362 : 1022-1029, 2010. 